\title{
Proposta de um modelo de gestão de estoques: um estudo de caso em uma empresa de pequeno porte do ramo alimentício na cidade de Marabá-PA
}

Quezia Dilma Carneiro de Oliveira Dias

aromaquezia@hotmail.com

Universidade do Estado do Pará (UEPA) Marabá, Pará, Brasil

Vanessa Mirelly da Silva Santos vanessamirellyvanessamirelly@gmail.com Universidade do Estado do Pará (UEPA), Marabá, Pará, Brasil

Nathália Jucá Monteiro nathalia2210@yahoo.com.br Universidade do Estado do Pará (UEPA) Belém, Pará, Brasil

Reimison Moreira Fernandes moreira.caldas97@gmail.com Universidade do Estado do Pará (UEPA), Marabá, Pará, Brasil

\begin{abstract}
RESUMO
Frente a um mercado altamente competitivo, as empresas buscam um posicionamento que possibilite atender seus clientes com qualidade, ao mesmo tempo em que possam reduzir os custos envolvidos em seus processos. Para alcançar esse equilíbrio, é fundamental a utilização de uma gestão de estoques bem estruturada. Neste contexto, este trabalho apresenta propostas de adequações ao modelo de gestão de estoques utilizado pelo setor de administração de matérias-primas de uma fábrica do ramo alimentício situada em Marabá-PA, baseadas nos indicadores de desempenho: Acurácia de Estoque, Giro de Estoque e Cobertura de Estoque e nas ferramentas de Planejamento e Controle da Produção (PCP): Estoque de Segurança E Ponto do Pedido. A análise do processo consistiu no mapeamento do atual modelo de gestão de estoques da empresa, que possibilitou a identificação de falhas e a proposição de melhorias para redução das falhas no processo. Como resultado do trabalho, foram elaboradas propostas de adequações, ao modelo de gestão de estoques da empresa, construindo-se um novo mapa de processo com as adequações propostas, para que às necessidades da organização sejam melhor atendidas; por meio da ferramenta $5 \mathrm{~W} 1 \mathrm{H}$ foi possível desenvolver um plano de ação, a fim de possibilitar à futura aplicação das melhorias, para que haja redução nos custos decorrentes de perdas e atrasos, contribuindo para a melhora na competitividade da empresa.
\end{abstract}

PALAVRAS-CHAVE: Gestão de estoque. Planejamento e Controle da Produção (PCP). Indicadores de desempenho 


\section{INTRODUÇÃO}

A rapidez nas mudanças do mercado atual impulsionadas pela alta tecnologia tem feito com que as respostas das empresas, frente a este cenário, sejam flexíveis e adaptativas. Neste contexto a Administração de Materiais tornase importante para a estabilidade e sobrevivência da organização no mercado, tendo em vista os conhecimentos que ela possibilita para a organização.

Segundo Dias (2012), a administração de estoques deve ser feita para obter disponibilidade de materiais a qualquer processo, através de um controle de estoques integrado e controlado por um sistema de quantidades e valores, ou seja, a administração exerce a função de controlar as necessidades existentes no processo produtivos total desde as matérias primas, produtos intermediários e acabados.

A área da gestão de estoques pode ser compreendida como menos importante para as empresas, entretanto o movimento de revalorização da gestão dos estoques na manufatura, de acordo com Corrêa (2010), mostra-se com extrema importância para atingir os objetivos estratégicos da empresa além de reduzir custos operacionais entre outros fatores importantes.

Observa-se uma necessidade das organizações no que diz respeito à manutenção adequada dos estoques, tendo pleno conhecimento que o mesmo é visto como capital imobilizado e gerador de custos, sendo assim Martins et al. (2011) explicam que a gestão de estoques constitui uma série de ações que permitem ao administrador verificar se os estoques estão sendo bem utilizados, bem localizados em relações aos setores que deles utilizam, bem manuseados e bem controlados.

Uma eficiente gestão de estoques possibilita à organização obter melhorias significativas na sua administração, uma vez que repercute em uma melhora na eficiência da realização da produção planejada, traz maior segurança nas tomadas de decisões, além de prevenir possíveis atrasos na entrega de pedidos (MONTANHEIRO; FERNANDES, 2008).

No que tange as micro e pequenas empresas (MPE), pesquisas aprontam que seu papel é de destaque na economia do país. De acordo com o Serviço de Apoio às Micro e pequenas Empresas (SEBRAE) (2015a), em 2001 as MPEs representavam 23,2\% do Produto Interno Bruto - PIB - brasileiro. Já em 2011, este percentual passou para $27 \%$. Em valores absolutos da época isto significava um aumento de R\$ 144 bilhões em 2001 para R\$ 599 bilhões em 2011. Entretanto, o Portal Brasil (2012) por meio de pesquisas, alertou que no ano de 2010 quase $58 \%$ das empresas de pequeno porte encerraram suas atividades antes de completarem cinco anos de existência.

O presente artigo tem como objetivo propor adequações ao modelo de gestão de estoques utilizado por uma fábrica do ramo alimentício, baseando-se nos principais Indicadores de Desempenho da gestão de estoques e nas ferramentas de Planejamento e Controle da Produção (PCP), sendo que a fim de nortear a pesquisa busca-se responder a seguinte pergunta: Quais adequações devem ser empregadas ao modelo de Gestão de Estoques utilizado por uma fábrica industrial de pequeno porte do ramo alimentício situada na cidade de Marabá-PA? 
O artigo está organizado em seis seções. A primeira é a introdução, na qual consta a pergunta de pesquisa e o objetivo do trabalho. Na segunda encontra-se o referencial teórico, o qual aborda temas relevantes para a realização da pesquisa. Em seguida, tem-se a metodologia, onde são abordados a classificação do trabalho e suas etapas. Na quarta seção, tem-se os resultados e discussões, apresentando o trabalho em si. Já na quinta seção são expressas as considerações finais e propostas de trabalhos futuros. Por fim, são apresentadas as referências utilizadas no artigo.

\section{REFERENCIAL TEÓRICO}

\section{GESTÃO DE ESTOQUE}

Segundo Moura (2004), estoque é considerado um conjunto de bens armazenados, com características próprias e com funções específicas, que atendem aos objetivos e necessidades que a empresa carece. Todo item armazenado em um depósito, galpão, almoxarifado, prateleira, gaveta ou armário para ser utilizado pela empresa em qualquer de suas atividades, é considerado um item do estoque da organização.

Para Ballou (2006) os estoques são acumulações de matérias-primas, suprimentos, componentes, materiais em processo e produtos acabados. As várias faces do estoque podem ser encontradas em diversos pontos do canal de produção e logística das empresas como mostra a Figura 1.

Figura 1 - Estoques na cadeia de suprimento

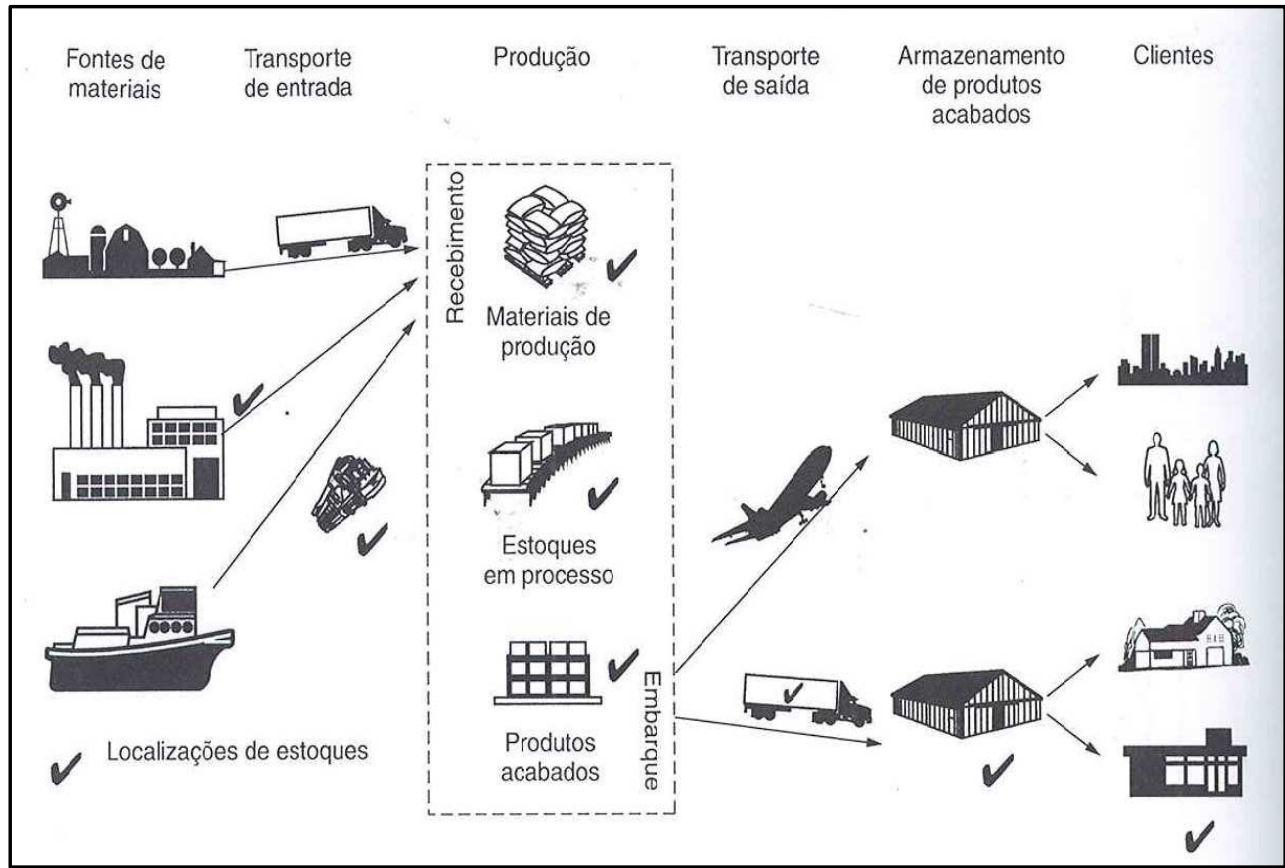

Fonte: BALLOU (2006)

Corrêa, Gianesi e Caon (2011) afirmam que os estoques são usados como reguladores da taxa de demanda e oferta. Os estoques são definidos em três 
grandes grupos: de matérias-primas, de produto semiacabado e de produtos acabados.

Segundo Ballou (2015), "a armazenagem de mercadorias prevendo seu uso futuro exige investimento [...]. O ideal seria a perfeita sincronização entre oferta e demanda de maneira a tornar a manutenção de estoques desnecessária". Ballou (2006) afirma que os custos de manutenção do estoque podem representar de $20 \%$ até $40 \%$ do seu valor por ano. Por este motivo, administrar com cuidado os níveis de estoque é economicamente sensato.

De acordo com Chopra e Meindl (2016), o estoque é o principal fator gerador de custo em uma firma quando mal administrado. A gestão de estoque tem papel fundamental nas organizações, sendo que para Ching (2010), ela possui três principais objetivos: planejamento, controle e melhoria do sistema de gestão. 0 planejamento ocorre a partir da determinação de valores que o estoque terá ao decorrer do tempo, além da disposição das datas de entradas e saídas em seu ponto de pedido. Os registros dos dados reais que correspondem o planejamento estão relacionados ao controle, consistindo, ainda, em realizar a comparação dos dados de controle com os dados do planejamento, identificando desvios durante o processo. Por fim, o sistema de gestão tem como objetivo melhorar o processo e consiste em, após realizado o controle, prestar feedback ao sistema para que todas as ações estejam alinhadas às decisões tomadas.

O conceito de gestão de estoque é muito amplo, composto de várias etapas desde a compra do fornecedor, passando por toda a transformação no processo produtivo e ponto final e entrega do produto final ao cliente. A Figura 2 apresenta a abrangência do conceito de gestão de estoque ao decorrer dos seus estágios.

Figura 2 - Gestão de estoque e o fluxo de material

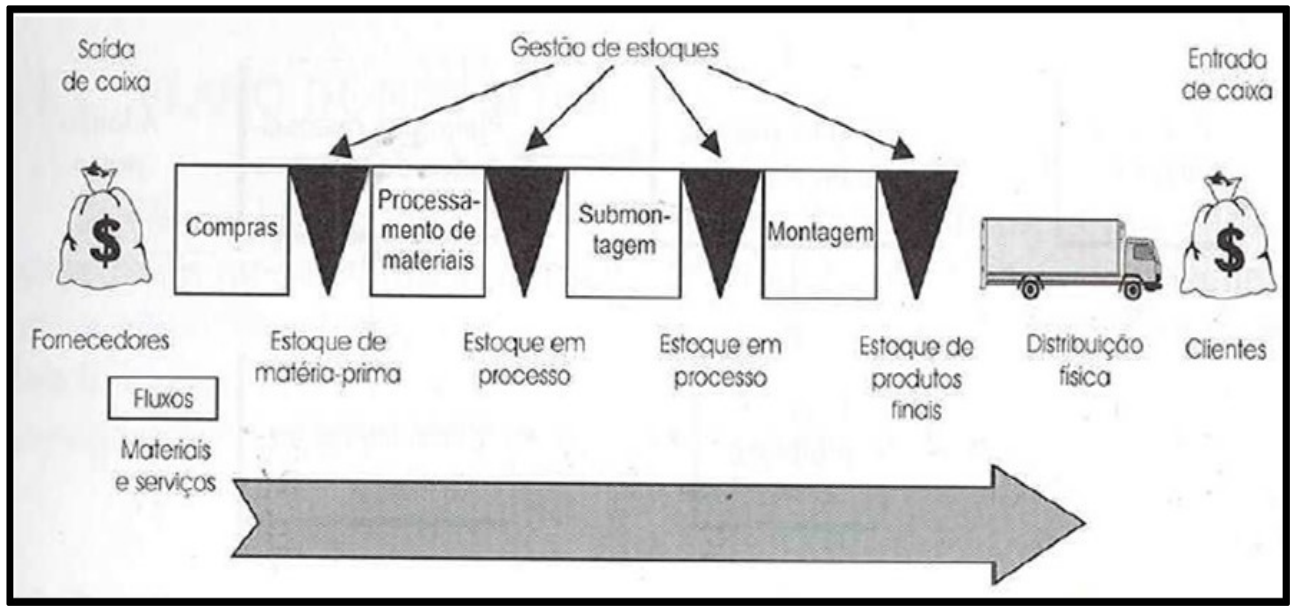

Fonte: BALLOU (2006)

De acordo com Fleury (2008), a decisão de localizar os estoques tem como papel perceber se estão centralizados ou descentralizados dentro da organização. Com base neste preceito, e de acordo com as características específicas de cada negócio, obtém-se a escolha de consignação de alguns materiais ou até mesmo optar por não manter estoques. $O$ autor afirma que quatro são os fatores que influenciam na localização dos estoques: 
- Giro de material: A tendência à descentralização em galpões é maior quando o giro é maior, pois riscos associados à obsolescência e perecibilidade são menores. Os custos fixos de armazenagem possuem uma parcela menor em materiais com giro alto;

- Lead time de resposta: Quanto maior o tempo de resposta deste a implantação do pedido até ao atendimento dele, maior é a tendência à descentralização dos estoques, devido a proporcionar um atendimento mais rápido e eficiente;

- Nível de disponibilidade exigida pelos mercados: Quanto maior for o nível de serviço, maior a tendência de colocar estoques mais próximos do cliente;

- Valor agregado: Quanto maior for o valor agregado, maior será a tendência à centralização dos estoques, devido a este valor implicar em um alto custo de oportunidade, assim devendo centralizar-se por questões de custo e para um maior controle.

Fleury (2008) conclui que o conhecimento desses quatro elementos pode levar o gestor a tomar a decisão mais adequada. Destacam-se duas situações que ocorrem, consignação de materiais e não manutenção dos estoques. Algumas condições favoráveis a consignação são: giro de estoques alto, alta criticidade do material e elevado valor agregado. Já em relação às condições favoráveis a não manutenção dos estoques estão: baixo giro de estoque, pequena exigência em relação a disponibilidade imediata e alto valor agregado.

O ponto de reposição ou ponto de pedido, segundo Ching (2010), tem como função dar início ao processo de ressuprimento dos materiais no tempo hábil a fim de não ocorrer erros, dependendo diretamente do consumo médio e do lead time de resposta. Seu cálculo pode ser feito a partir Equação 1.

"Ponto Pedido $=$ Estoque Segurança + (Consumo x Tempo Reposição)"

O momento do ressuprimento também está ligado diretamente ao giro do material, valor agregado e risco à obsolescência. Dependendo do tipo do material e dos fatores citados anteriormente, o ponto de pedido pode ser postergado ou adiantado.

Segundo Corrêa, Gianesi e Caon (2011), o estoque de segurança é definido como o estoque de produtos ou serviços mantidos para que não falte produtos para atender ao cliente. Segundo Tubino (2017) para calcular o tamanho do estoque de segurança utiliza-se a Equação 2:

QS=K.MAD

Onde:

$\mathrm{K}$ = número de desvios padrões.

$M A D=$ desvio médio absoluto

Para se obter o valor de k, primeiro estabelece-se o nível de serviço que se deseja para o item, conforme Tabela 1. 
Tabela 1 - Relação de nível de serviço com número de desvios padrões (k).

\begin{tabular}{|cc|} 
Nível de Serviço & $\mathbf{K}$ \\
$\mathbf{8 0 \%}$ & 0,84 \\
$\mathbf{8 5} \%$ & 1,03 \\
$\mathbf{9 0 \%}$ & 1,28 \\
$\mathbf{9 5 \%}$ & 1,64 \\
$\mathbf{9 9 \%}$ & 2,32 \\
$\mathbf{9 9 , 9 9 \%}$ & 3,09 \\
\hline
\end{tabular}

Fonte: Tubino (2017).

Para calcular o valor do MAD, utiliza-se a Equação 3.

$$
M A D=\frac{\sum_{t=1}^{n}\left|\left(\mathrm{y}_{t}-\hat{\mathrm{y}}_{t}\right)\right|}{n}
$$

Onde:

$\sum_{t=1}^{n}=$ indica soma de todos os termos, desde a primeira posição $(\mathrm{t}=1)$ até a posição $n$

$\mathrm{y}_{t}=$ valor na posição t no conjunto de dados

$\hat{\mathrm{y}}_{t}=$ média aritmética dos dados

$\mathrm{n}=$ quantidade de dados

De acordo com Pozo (2010), estoque de segurança, é uma quantidade mínima de peças que devem existir no estoque com a função de cobrir as possíveis variações do sistema, as quais podem ser: eventuais atrasos no tempo de fornecimento por parte do fornecedor, rejeição do lote de compra ou aumento na demanda do produto. Sua finalidade é não afetar o processo produtivo e sim, principalmente, não acarretar transtornos pela falta do material.

\section{CONTROLE DE ESTOQUE}

Segundo Pozo (2016), o termo controle de estoques tem como função estipular os diversos níveis de materiais e produtos que a empresa tem como necessidade manter. Ter um planejamento para todas as atividades de controle de estoque é fundamental para a redução dos custos operacionais da empresa.

De acordo com Ballou (2015), as empresas geralmente fabricam diversos produtos em etapas diferentes de seu ciclo de vida e o planejamento e distribuição dos mesmos é feito de forma individual, ou seja, é por meio do controle de estoques que a empresa determinará os níveis de cada item necessário para a realização das atividades cotidianas. No campo da administração de materiais, o controle dos níveis de estoques tem uma função de primordial importância, exercendo função estratégica em diversas organizações que têm em seus ativos estoques de qualquer natureza. Segundo Viana (2009), os estoques representam componentes de extrema significância para a empresa no que diz respeito aos aspectos econômicos, operacionais e financeiros. 
Os custos associados ao estoque são diversos. Conforme Dias (2012), todo armazenamento pode gerar determinado custo para a organização como: juros; aluguel; equipamentos de movimentação; depreciação; deterioração; obsolescência; salários; seguros; conservação. Entretanto, os estoques são fundamentais para qualquer organização e utilizá-los da maneira certa reduz custos altíssimos. Segundo Ching (2010), os custos associados aos estoques podem ser classificados em três:

- Custo de pedir: São os custos fixos administrativos agregados ao processo de aquisição das quantidades solicitadas para reabastecimento dos estoques. Podem estar relacionados aos custos de preencher pedido de compra, de processar os serviços burocráticos, na contabilidade e no almoxarifado, e de receber o pedido e de efetuar a verificação contra a nota e a quantidade física;

- Custo de manter estoques: São todos os custos necessários para manutenção da mercadoria estocada por certo período. São os custos de armazenagem, de seguro, de deterioração e obsolescência e de furto;

- Custo total: É a soma do custo de pedir e de manter estoques.

Desta forma, a formação dos diferentes tipos de estoques presente em uma organização levará em consideração o capital disposto a ser utilizado buscando o pleno atendimento das necessidades da empresa.

\section{INDICADORES DE DESEMPENHO}

Com os indicadores de desemprenho de estoque, o administrador mensura se as ações adotadas na gestão de estoques da empresa respeitam o bom uso e manuseio dos materiais, se ela está trazendo resultados positivos e quais as ações necessárias a serem tomadas caso esta gestão apresente falhas.

Segundo Martins et al. (2011), inventário físico consiste na contagem dos itens em estoque nas empresas. Os mesmos autores afirmam que inventário físico é aplicado em dois modos: periódico e rotativo. Se houver diferenças entre o inventário físico e o contábil, deve-se tomar medidas para sanar esta irregularidade.

O inventário periódico ocorre quando os estoques são inventariados em determinados períodos pré-determinados pela empresa, onde se faz a contagem física de todos os itens do estoque. Devido à contagem total de itens exige-se um número maior de pessoas com a função de contar. É considerada uma força tarefa, pois a contagem deve ser efetuada no menor tempo possível (MARTINS et al., 2011).

Já o inventário rotativo ocorre quando, permanentemente, alguns itens préescolhidos pela empresa são inventariados. Neste tipo de inventário faz-se um cronograma de contagem para garantir que ao longo do período todos os itens sejam contados (MARTINS et al., 2011).

Essa política exigirá certo número de pessoas exclusivamente para contagem, em período integral, no ano todo.

A acurácia dos estoques pode ser um dos indicadores utilizados. Ela é uma ferramenta ideal para medir as divergências entre estoque físico e contábil. A acurácia dos estoques, de acordo com Martins et al. (2011) é mensurar a 
porcentagem de itens corretos presente no inventário, tanto em valor quanto em quantidade, conforme a Equação 4.

$$
\text { Acurácia dos Estoques }=\frac{\text { Número ou valor de itens corretos }}{\text { Número ou valor total de itens }}
$$

O giro do estoque também é um indicador. Martins et al. (2011) informam que o giro de estoque tem como função medir quantas vezes, por unidade de tempo, o estoque se renovou e girou.

A informação oferecida pelo giro de estoque de qual item tem maior consumo no estoque, traz ao gestor a conscientização que a falta do mesmo gerará problemas para a empresa, o cálculo pode ser realizado mediante a Equação 5.

$$
\text { Giro do Estoque }=\frac{\text { Quantidade consumida no período }}{\text { Quantidade do estoque no período }}
$$

Martins et al. (2011) também mencionam o indicador cobertura de estoque. Ainda segundo os mesmos autores, este indicador mostra o número de unidades de tempo em dias, que o estoque será suficiente para cobrir as necessidades dos usuários. Tem-se a sua utilização para materiais fundamentarias no processo produtivo, pois fomenta dados de quando estoque será consumido por inteiro, o cálculo da cobertura de estoque pode ser realizado conforme a Equação 6.

$$
\text { Cálculo da Cobertura }=\frac{\text { Número de dias do período }}{\text { Giro }}
$$

\section{FERRAMENTAS DE ANÁLISE}

\section{Curva $A B C$}

A curva $A B C$ segundo Lustosa et al. (2008) é o sistema de que surgiu em grandes organizações que possuíam centenas ou milhares de tipos de itens em estoque para serem controlados, diante da imensa dificuldade para controlar todos os itens sem computador. Para isso, Joseph Moses Juran desenvolveu um sistema que pudesse determinar a importância de cada item, traçando uma classificação de prioridade de controle para cada item. Este modelo ficou conhecido também como 80/20 ou diagrama de Pareto.

A curva $A B C$ tornou-se uma importante aliada da gestão de estoques, pois esta consiste na classificação da importância dos produtos que são vendidos, auxiliando os gestores na tomada de decisão no que diz respeito aos estoques. $O$ seu uso vem sendo praticado desde a criação de seu conceito.

Para Dias (2012), a curva ABC é uma ótima ferramenta para os gestores, pois mensura e classifica os diversos itens estocados de acordo com sua maior importância, justificando a atenção e tratamento que alguns itens devam possuir devido ao seu alto consumo e valor agregado.

A abordagem $A B C$ consiste em separar as listas de materiais estocados em três grupos distintos, estes grupos são classificados de acordo com a sua demanda valorizada e eles podem ser mensurados pela multiplicação do seu custo unitário e consumo anual (VOLLMANN et al., 2006). A classificação dos grupos ocorre da seguinte forma: 
- Categoria A: São os itens que possuem um alto valor e representam $20 \%$ dos itens do estoque total e correspondem a $80 \%$ do custo anual das compras. São considerados os itens mais importantes, merecendo a maior parte do esforço da gestão;

- Categoria B: Entende-se como os itens que possuem um consumo intermediário, constituídos por $30 \%$ dos itens de estoque e custo anual de compras de $15,5 \%$ do total;

- Categoria C: Itens com baixo consumo constituem 50\% dos itens do estoque e correspondem a apenas $5 \%$ do custo anual de compras.

Tubino (2017) coloca que a demanda valorizada ou valor de estoque é um dos critérios mais adotados para a utilização da Classificação $A B C$ como método de se classificar os itens em estoque, neste tipo de abordagem é observado o investimento unitário de cada item em estoque multiplicado pela demanda de cada item. A metodologia de aplicação da classificação consiste nos passos descritos por Corrêa e Corrêa (2012), os quais são listados abaixo:

- Passo 1: Determinar a quantidade total utilizada de cada item em estoque no ano anterior, ou viabilizar as projeções de uso futuro de cada item onde é possível;

- Passo 2: A partir da moeda forte determinar o custo médio de cada item em estoque;

- Passo 3: Determinar o custo de uso anual de cada item, encontrado pelo custo médio levantado em 2, dividido pela quantidade utilizada levantada em 1;

- Passo 4: Colocar todos os itens em valor decrescente do custo de uso encontrado no item anterior;

- Passo 5: Calcular a acumulação de valores de uso de toda lista na ordem definida anteriormente;

- Passo 6: Colocar em termos percentuais os valores encontrados no item anterior de acumulação de valores de uso para o total de itens;

- Passo 7: Plotar num gráfico os valores percentuais;

- Passo 8: Definir as regiões A, B e C pela inclinação da curva, sendo respectivamente grande inclinação, média inclinação e baixa inclinação.

Segundo Corrêa e Corrêa (2012) para a construção da Curva ABC alguns pontos são indispensáveis, são eles: a relação de itens no período de tempo em que está sendo feita a análise; referências e nome dos itens; preços unitários atualizados; valor total do consumo; classificação dos itens em ordem decrescente; somatória do faturamento total; determinação dos itens da Classe A como $80 \%$ do faturamento, Classe B como $15 \%$ e Classe C como $5 \%$; definição dos itens de cada Classe.

\section{Mapeamento de Processos}

Os processos podem ser classificados como uma série de atividades no qual interligam pessoas e organização de maneira eficiente. Quando coesas, elas 
agregam valor e estão sempre em fase de aperfeiçoamento (KRAJEWSKI, RITZMAN e MALHOTRA, 2009).

Como um componente essencial, o mapeamento de processos pode permitir a redução de custos na prestação de serviços, decréscimo nas falhas de integração entre sistemas e melhora do desempenho da organização no qual implicam diretamente no gerenciamento e comunicação. O mapeamento de processos é uma excelente ferramenta para o melhor entendimento dos processos atuais além de eliminar e/ou simplificar aqueles que necessitam de mudanças (GOMES et al., 2015). Na Figura 3 são apresentados os passos para analisar os processos realizados na empresa a fim de identificar falhas.

Figura 3 - Análise de Processos

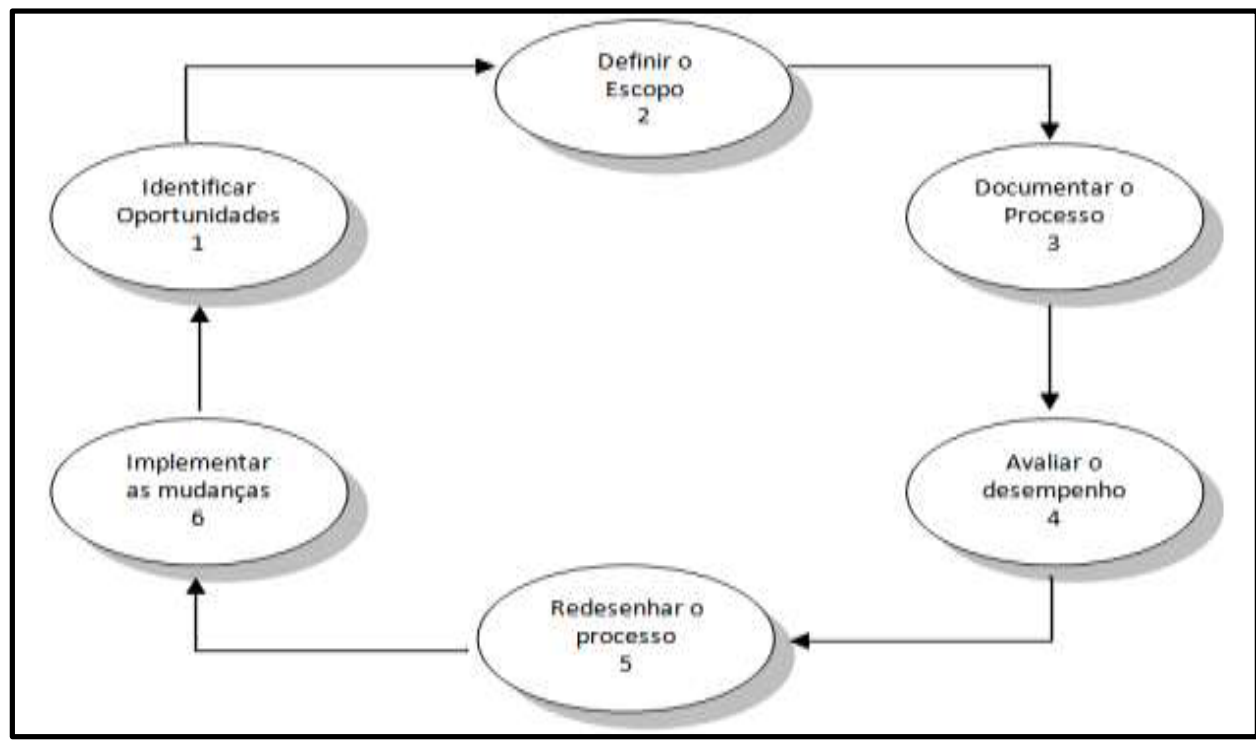

Fonte: Adaptado de Krajewski, Ritzman e Malhotra (2009)

Quanto à análise dos processos, trata-se de um acompanhamento acerca do trabalho executado e de como pode ser redesenhado. A análise de processos tem início pela identificação de uma nova oportunidade para aperfeiçoamento, passando pela definição de escopo, documentação de processos, avaliação do desempenho, redesenho do processo e termina com a implementação de um processo revisado. Segundo Krajewskiet et al., (2009), uma vez que a última etapa volta para o primeiro lugar, está cria um ciclo de aperfeiçoamento contínuo.

\section{Fluxograma}

Como ferramenta de gestão organizacional, o fluxograma pode ser percebido como um excelente mapa do funcionamento interno e externo em relação aos processos empresariais. Os fluxogramas apresentam figuras esquemáticas que indicam passo a passo de cada processo ou atividade a fim de ser estudada ou estruturada pela organização. Ele começa com uma questão/problema/missão/projeto, que necessite de um tratamento ou cuidado, dentro de uma equipe ou organização (SHETACH, 2011). 
Graficamente, os fluxogramas são o coração do mapeamento de processos de negócios (BARBROW; HARTLINE, 2015). Um fluxograma onde os papéis são designados indica um mapa de processo que consiste em formas que representam diferentes elementos de um fluxo de trabalho. Muitos tipos de forma adicionais representam vários elementos de fluxo de trabalho. Pode-se observar as atividades que estão sendo executadas na organização a partir da aplicação de formas geométricas (ou não) apresentadas na Figura 4.

Figura 4 - Itens utilizados na composição do fluxograma

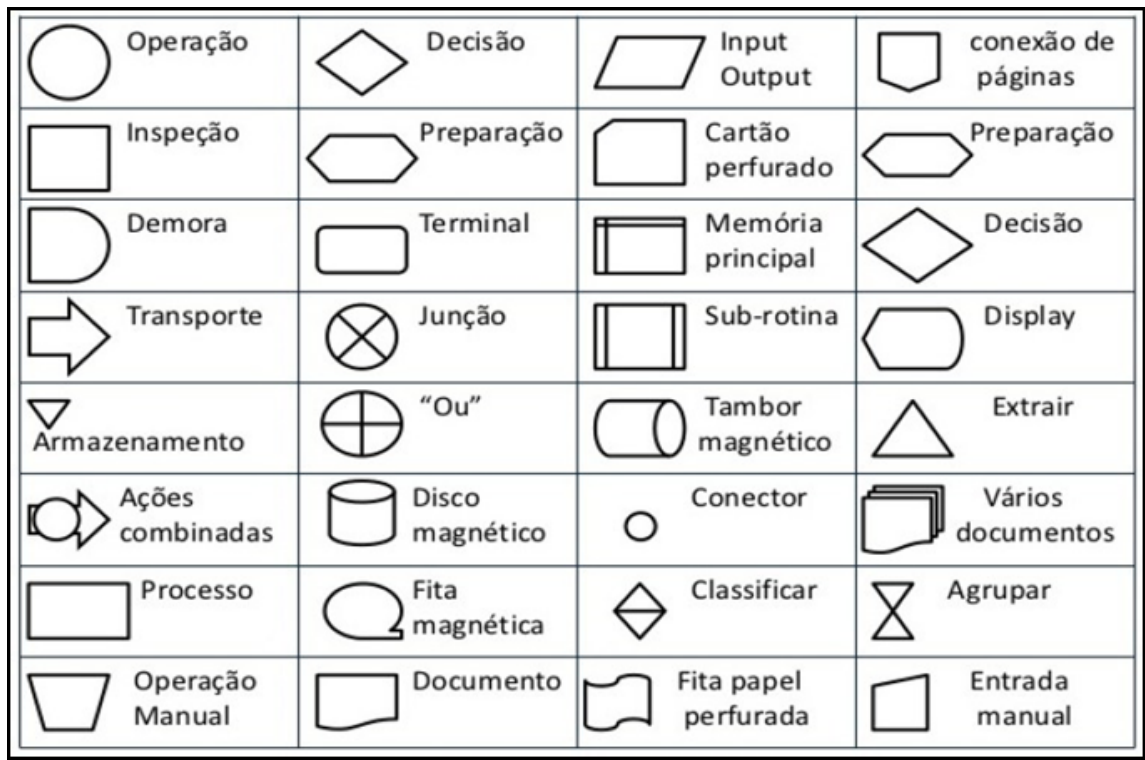

Fonte: Autoria própria em padrões ANSI (American National Standards Institute) (2019).

De acordo com Pinho (2007), um fluxograma traça o fluxo de informação, pessoas, equipamentos, ou materiais por meio das várias partes do processo. Os fluxogramas são traçados com formas geométricas em volta contendo uma breve descrição do processo e com linhas e setas que mostram a sequência de atividades. Uma vez que todos os passos do fluxograma foram documentados, é possível analisar o fluxograma para revelar áreas de problemas potenciais.

\section{$5 \mathrm{~W} 2 \mathrm{H}$}

A ferramenta da qualidade 5W2H é, segundo Lisboa e Godoy (2012), uma ferramenta prática que permite identificar dados e rotinas importantes de uma unidade de produção a fim de identificar quem é o responsável por qual função, o que faz e porque realiza tais atividades dentro da organização e como pode ser acompanhado na Figura 5. 
Figura 5 - Método 5W2H

\begin{tabular}{|l|l|l|l|}
\hline \multicolumn{3}{|c|}{ Método 5W2H } \\
\hline \multirow{3}{*}{$5 \mathrm{~W}$} & What & 0 que? & Que ação será executada? \\
\cline { 2 - 4 } & Who & Quem? & Quem irá executar/participar da ação? \\
\cline { 2 - 4 } & Where & Onde? & Onde será executada a ação? \\
\cline { 2 - 4 } & When & Quando? & Quando a ação será executada? \\
\cline { 2 - 4 } & Why & Por quê? & Por que a ação será executada? \\
\hline \multirow{2}{*}{$2 \mathrm{H}$} & How & Como? & Como a ação será executada? \\
\cline { 2 - 4 } & How much & Quanto custa? & Quanto custará para executar a ação? \\
\hline
\end{tabular}

Fonte: Adaptado de Lisbôa e Godoy (2012).

O método da ferramenta é constituído a partir de sete perguntas específicas no qual suas respostas programam soluções para as mesmas. Dependendo dos objetivos da empresa, a ferramenta pode ser utilizada como $5 \mathrm{~W} 1 \mathrm{H}$, eliminando algum fator que seja desnecessário para a situação desejada.

\section{METODOLOGIA}

Segundo Prodanov e Freitas (2013), do ponto de vista de sua natureza, esta pesquisa pode ser classificada como aplicada, pois objetiva gerar conhecimentos para futura aplicação prática, propondo soluções direcionadas a problemas específicos, que envolvam verdades e interesses diferenciados. O estudo em questão classifica-se desta forma por sugerir um modelo de gestão de estoque que melhor se adeque as necessidades da empresa estudada.

Com relação à abordagem, a pesquisa caracteriza-se como qualitativa e quantitativa. Qualitativa, pois de acordo com Gaither e Frazier (2012), nesse tipo de pesquisa os dados e informações são obtidos por meio de entrevistas não estruturadas, observação e análise de dados históricos da empresa, além de pesquisas bibliográficas que contribuam para a resolução do problema estudado, que é o caso do presente trabalho. Por outro lado, a pesquisa quantitativa se dá a partir das informações coletadas que serão traduzidas em números, por meio de recursos e técnicas estatísticas a fim classificá-las e analisá-las (PRODANOV; FREITAS, 2013).

Este estudo é caracterizado como exploratório quanto aos seus propósitos, pois conforme Gil (2017) esse tipo de pesquisa visa abranger um planejamento flexível, visto que as variáveis envolvidas no estudo serão consideradas, esclarecendo-as da melhor forma possível, para que o contexto em que estão inseridas seja compreendido.

Quanto aos procedimentos técnicos empregados, a pesquisa se caracteriza como estudo de caso, uma vez que, ao avaliar o atual sistema de gestão empregado no setor de administração de matérias-primas da empresa, é possível compreendê-lo em seu contexto, sendo possível propor melhorias baseadas em conceitos de planejamento e controle da produção e indicadores de desempenho (GANGA, 2012).

As principais etapas realizadas para o desenvolvimento da pesquisa estão listadas segundo sua ordem de ocorrência: 
a) Mapeamento e análise do processo atual: Realizou-se o mapeamento do processo atual da gestão de estoques da empresa, a fim de analisá-lo e identificar as falhas. Essa etapa foi desenvolvida pelos seguintes meios:

- Entrevistas: Inicialmente foram realizadas entrevistas não estruturadas com os gestores da empresa, responsáveis pelo processo de administração de matérias-primas e com outros funcionários ligados a este setor, a fim de esclarecer o objetivo do trabalho e obter conhecimento do funcionamento da empresa e de como ocorre o ciclo de reposição dos insumos. Este instrumento trouxe o auxílio na obtenção de dados que não se encontram no banco de dados e arquivos existentes;

- Visitas ao local: Tais visitas ocorreram periodicamente durante a realização do estudo, e tiveram como objetivo conhecer o contexto das atividades e observar detalhadamente o fluxo interno das matérias-primas;

- Observação do histórico da empresa: Foram consultados os sistemas gerenciais e arquivos documentais que auxiliam no controle de entradas e saídas de insumos, extraindo deles informações e dados históricos, visando à escolha da matéria-prima mais utilizada, por meio da classificação $A B C$, e a identificação de falhas e perdas no inventário; o período analisado foi de 1 (um) ano, iniciando no mês de Janeiro de 2017 com término no mês de Dezembro de 2017, optou-se por esse período, por conter os dados históricos completos. Os dados coletados foram organizados em tabelas, gráficos, mapas e fluxogramas de processos, que permitiram a manipulação e tratamento, sendo que após o processamento dos dados, as falhas no processo puderam ser claramente identificadas;

b) Verificação da adequação dos indicadores de desempenho e das ferramentas de PCP: Com base nos dados obtidos na organização foram realizados os cálculos referentes aos indicadores de desempenho: Acurácia dos Estoques, Giro de Estoque e Cálculo da Cobertura; e as ferramentas de PCP: Estoque de Segurança e Ponto do Pedido, a fim de demonstrar o nível de efetividade do modelo atual de gestão de estoques e fundamentar a elaboração das propostas de melhorias;

c) Formulação de melhorias para o modelo atual de gestão de estoques: $A$ partir do mapeamento do processo e identificação das falhas, bem como a comprovação do nível de efetividade do modelo atual de gestão de estoques, por meio dos cálculos dos indicadores de desempenho e das ferramentas de PCP, propuseram-se medidas para reduzir ou eliminar as falhas; elaborou-se um novo mapa de processos com as adequações propostas, permitindo uma melhor visualização e compreensão das mesmas; por fim, utilizando a ferramenta $5 \mathrm{~W} 1 \mathrm{H}$ construiu-se um plano de ação, a fim de possibilitar à futura aplicação das medidas formuladas.

Os dados e informações obtidos foram dispostos em tabelas, gráficos, mapas e fluxogramas de processos, que permitiram a organização e quantificação, possibilitando a compreensão do processo, a melhor visualização das atividades envolvidas e a identificação das falhas. O software Microsoft Office Excel 2016 foi utilizado como ferramenta para manipular e tratar os dados, para elaboração dos fluxogramas de processos, a ferramenta utilizada foi o software lo Draw 2018. 


\section{ESTUDO DE CASO}

\section{A empresa}

A empresa objeto de estudo é uma fábrica de salgados de pequeno porte localizada no Sudeste do Estado do Pará, na cidade de Marabá/PA. Foi fundada no ano de 2009 pelos atuais proprietários, e fornecia inicialmente uma reduzida variedade de produtos. Após alguns anos de funcionamento houveram ampliações nas dependências da fábrica, o que possibilitou a expansão do mix de produtos e aumento no quadro de funcionários, que hoje é formado por aproximadamente 30 colaboradores.

Atualmente, a fábrica trabalha com quatro linhas de produção: Lanchonete, Supermercado, Festa e Especial; fornecendo salgados de variados tipos e recheios, tais como: coxinhas, bolinhas de queijo, empadinhas, pasteis assados e fritos, mini-pizzas, quibes, entre outros. A Tabela 2 demonstra o faturamento anual de cada linha de salgados.

Tabela 2 - Faturamento anual das linhas oferecidas pela empresa estudada.

\begin{tabular}{l|l}
\multicolumn{2}{c|}{ Faturamento ano 2017} \\
Lanchonete & $R \$ 470.553,17$ \\
\hline Supermercado & $R \$ 389.251,09$ \\
\hline Festa & $R \$ 119.718,33$ \\
\hline Especial & $R \$ 70.319,66$ \\
\hline Total & $R \$ 1.049 .842,25$ \\
\hline
\end{tabular}

Fonte: Autoria própria (2019)

Os valores da Tabela 2 estão ilustrados na Figura 6. Dessa forma, pode-se visualizar em porcentagem a contribuição de cada linha de salgados no faturamento geral da empresa.

Figura 6 - Faturamento anual das linhas oferecidas pela empresa estudada.

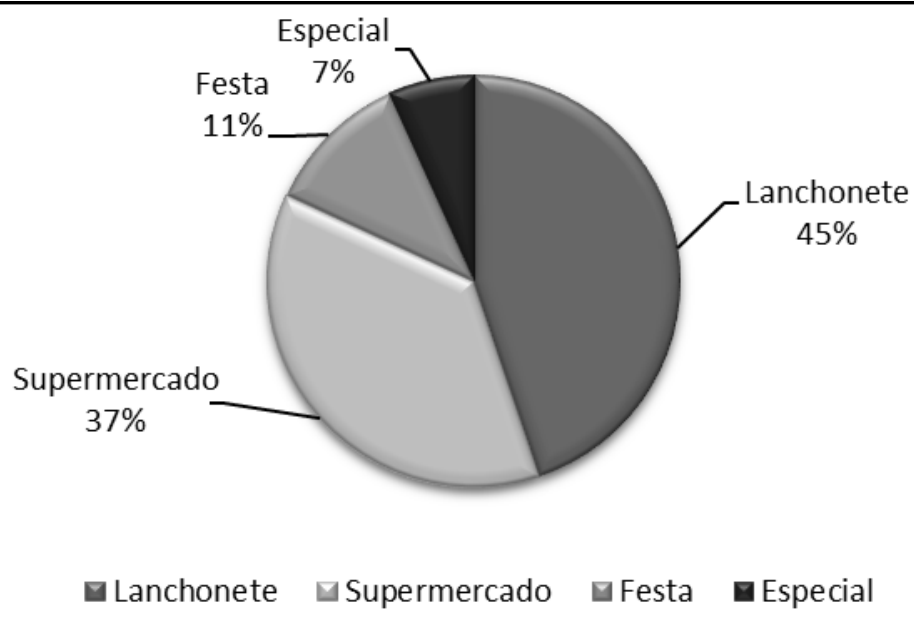

Fonte: Autoria própria (2019) 
Após analisar os dados de faturamento, foram escolhidas as duas linhas mais rentáveis para a empresa, sendo elas as linhas: Lanchonete e Supermercado. Os salgados de lanchonete são fornecidos para lanchonetes conveniadas à fábrica a partir do contato a fim de encomendar seus pedidos. Já os salgados de supermercado visam à venda no atacado para supermercados em geral, possuindo uma grande variedade de produtos disponíveis para sua comercialização.

\section{Mapeamento e análise do processo atual}

Durante a realização do estudo por meio da observação e entrevista com os gestores e funcionários, cada atividade da gestão de estoques atual foi analisada, observando suas especificações. O primeiro passo foi à elaboração do mapa de processo geral que abrange todas as etapas da gestão de estoques, desde o início até a última função do fluxo logístico de matérias-primas. Criado com o propósito de esclarecimento dos processos existentes na empresa como aquisição, armazenagem e utilização das matérias-primas, o mapa de processos ao ser analisado criticamente pelos autores forneceu as falhas existentes no atual método da empresa, possibilitando correção, mediante as propostas de melhorias.

A gestão de estoques atual da empresa foi separada em quatro partes para melhor visualização e análise dos processos: requisição de compras, recebimento, armazenagem e retiradas do estoque. $\mathrm{O}$ bom funcionamento da fábrica diz respeito ao bom funcionamento do estoque, tendo em vista que se houver a falta de algum item, alguma das quatro operações do almoxarifado falhou.

A etapa de requisição de compras compreende-se desde a identificação de uma necessidade para suprir a produção até o ato de compra final. 0 processo tem início com a emissão do pedido de compras, no qual na maior parte do tempo é com emergência, tendo em vista que o estopim do pedido de compras se dá a partir das exigências do setor de produção da fábrica ao identificar que não há no estoque o produto desejado; a supervisora de produção anota quais os materiais necessários para compra, ou seja, aqueles que estão em falta e são necessários; o pedido de compras é emitido e analisado pelo responsável pelas compras da empresa (Dono da empresa) para averiguar se há recursos disponíveis, a próxima tarefa é orçar o valor dos produtos com os fornecedores, que atendem por telefone ou pessoalmente. Após averiguar qual fornecedor oferece o melhor custo $x$ benefício, confirma-se a compra e o fornecedor verifica se há como efetivar a mesma, se aceita será expedida para entrega.

O segundo procedimento abrange o recebimento de toda mercadoria solicitada que será, posteriormente, armazenada no estoque da empresa. 0 recebimento tem início com a chegada da mercadoria pela transportadora ou por meio do regresso do dono à empresa com o pedido de compra. Confere-se a NF (nota fiscal) no intuito de comparação do pedido de compras com a mercadoria recebida. Caso haja algo de errado nos dados da nota fiscal ou no volume da mercadoria recebida o fornecedor é contatado e a NF não é assinada pelo recebedor, além de informar o responsável pelo pedido de compra. O material só pode ser recebido e a NF assinada a partir da entrega correta do pedido emitido 
de compras. Após a conferência para o recebimento da mercadoria, a NF é repassada ao gestor da empresa, que a insere no sistema gerencial.

Ao final do processo de recebimento dos materiais, os funcionários separam os produtos na área de recebimento para os encaminhar ao seu local de armazenagem, feito isso, as matérias-primas são levadas para os armazéns e estocadas da maneira mais conveniente possível. Existem dois depósitos para estocagem de matérias-primas, sendo um para produtos frios, como: frango, presunto, calabresa e chocolates, e outro para produtos não perecíveis. Cada material é armazenado na área destinado à sua classe de materiais.

A última etapa do processo diz respeito a retirada do estoque, que se inicia com a chegada do funcionário em um dos armazéns até a retirada do material necessário para a continuidade do processo produtivo da fábrica. A retirada de qualquer material do estoque pode ser feita por funcionários da fábrica responsáveis pelo setor de produção. As requisições de materiais são fundamentadas nas necessidades dos colaboradores, logo os tais exploram as salas de. Na Figura 7 é apresentado o fluxograma do processo descrito acima.

Figura 7 - Mapa de processos atual da empresa

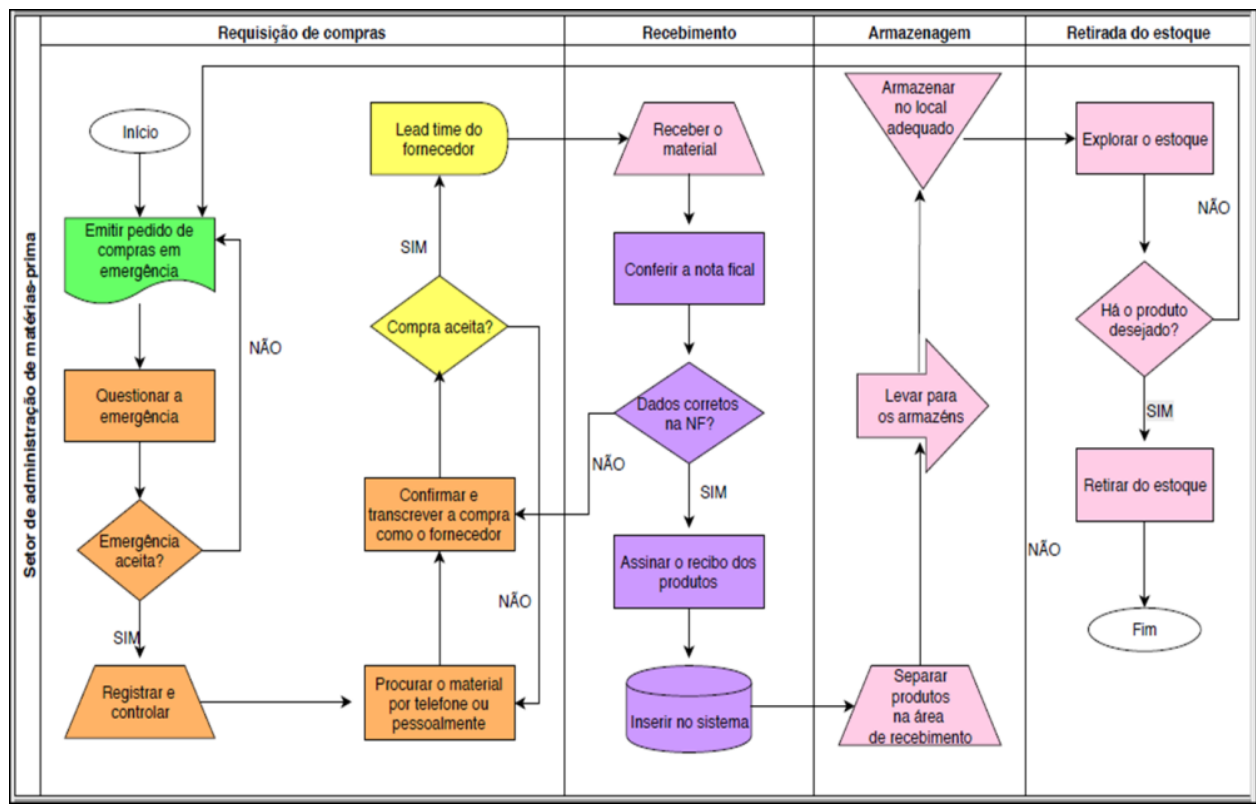

Fonte: Autoria própria (2019).

\section{Classificação $A B C$}

A elaboração da classificação $A B C$ se deu a partir da necessidade de conhecimento dos itens classificados como matérias-primas de maior representatividade para a produção das linhas de Lanchonete e Supermercado. Ao se deparar com a falta/perda de qualquer um dos materiais denominados como classe $A$, pode haver uma interrupção no processo produtivo das linhas, acarretando assim, prejuízos para a empresa. No Quadro 1, é possível visualizar de forma resumida os dados de cada classe da classificação ABC. 
Quadro 1 - Dados de cada classificação $A B C$

\begin{tabular}{|c|c|c|c|c|}
\hline $\begin{array}{c}\text { Classe de } \\
\text { Produtos }\end{array}$ & $\begin{array}{c}\text { Número } \\
\text { de Itens }\end{array}$ & $\%$ dos Itens & $\begin{array}{c}\text { Demanda } \\
\text { valorizada }(\mathrm{R} \$)\end{array}$ & $\%$ dos valores \\
\hline $\mathrm{A}$ & 11 & $19 \%$ & $\mathrm{R} \$ 347.911,02$ & $75 \%$ \\
\hline $\mathrm{B}$ & 17 & $30 \%$ & $\mathrm{R} \$ 94.002,34$ & $20 \%$ \\
\hline $\mathrm{C}$ & 29 & $51 \%$ & $\mathrm{R} \$ 25.236,61$ & $5 \%$ \\
\hline Total & 57 & $100 \%$ & $\mathrm{R} \$ 467.149,97$ & $100 \%$ \\
\hline
\end{tabular}

Fonte: Autoria própria (2019).

O Quadro 1 apresenta uma visualização simplificada e precisa da porcentagem que cada produto que compõe as linhas estudadas (lanches e supermercado), representa para a empresa em valores monetários. Os 11 (onze) primeiros são os mais importantes para a fábrica, em contrapartida sua variedade de produtos é bem menor que os demais itens, representam apenas $19 \%$ dos mesmos. A Figura 8 apresenta o gráfico da classificação $A B C$ no qual teve sua aplicação aos insumos existentes na fábrica para a produção das linhas de Lanches e Supermercado.

Figura 8 - Gráfico Classificação $A B C$

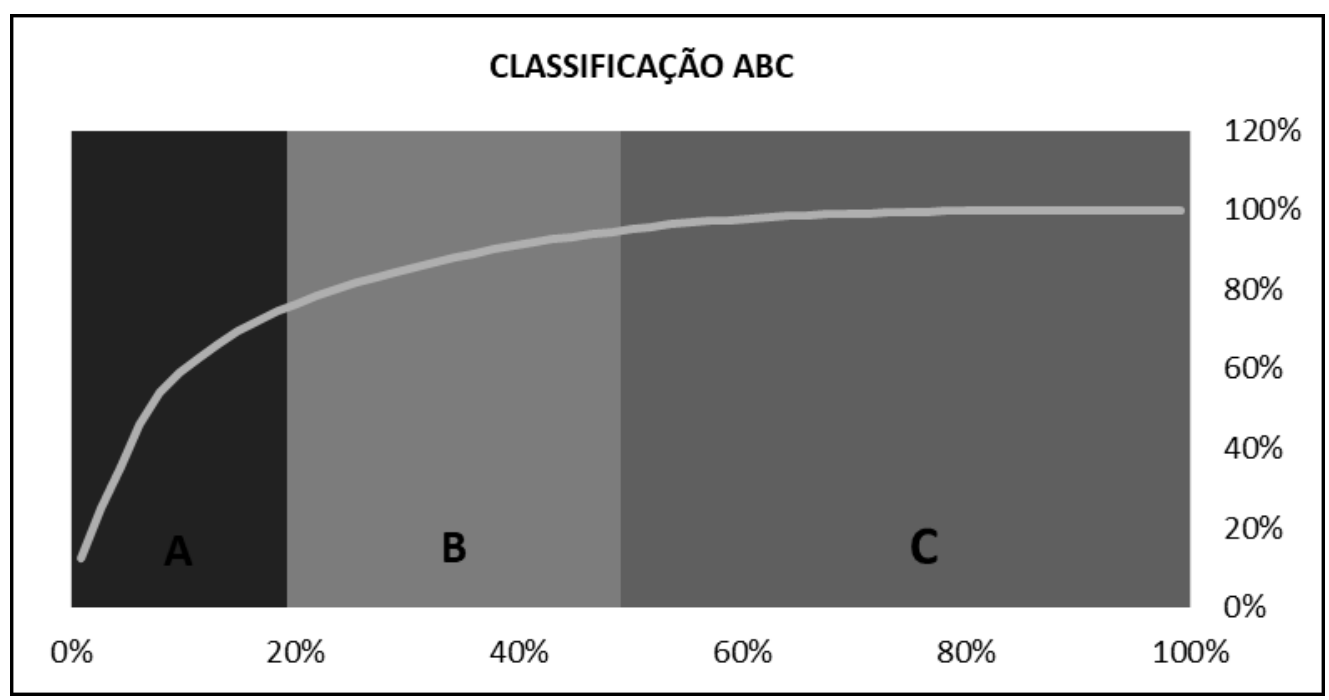

Fonte: Autoria própria (2019).

É possível observar que os 11 primeiros itens representam $75 \%$ dos custos de aquisição para a fábrica, enquanto que 17 itens, considerados os itens B, custam para a empresa $20 \%$ do total de gastos gerados pela compra de insumos. A maior quantidade de produtos (29 itens) representa para a empresa $5 \%$ dos valores relacionados aos custos de aquisição de matéria-prima.

\section{Cálculos dos indicadores de desempenho}

Inicialmente, foi aplicado o indicador Acurácia de Estoques, para identificar o nível de confiabilidade do estoque da empresa estudada. Os valores utilizados para calcular o indicador e seu respectivo resultado estão contidos na Tabela 3. 
Tabela 3 - Aplicação do indicador Acurácia de Estoques

\begin{tabular}{lc}
\multicolumn{2}{c}{ Indicador Acurácia de Estoques } \\
Total de itens & 57 \\
Itens corretos & 38 \\
Valor Acurácia & $67 \%$ \\
\hline
\end{tabular}

Fonte: Autoria própria (2019).

De acordo com Waller et al. (2006), o resultado do indicador é considerado insuficiente e demonstra que há deficiência no controle de estoques aplicado pela empresa, já que o ideal seria um resultado igual ou próximo a 100\%. Cada item contido no estoque da empresa é fundamental para manter o bom funcionamento da produção, um índice de 33\% de falhas entre o estoque físico e contábil representa riscos ao planejamento estratégico, e pode prejudicar os custos e o nível de serviço da empresa.

Foram aplicados mais dois indicadores de desempenho: Giro de estoque e Cobertura de estoque, nos produtos considerados classe A da empresa, a fim de medir tanto a eficiência do atual modelo de gestão de estoques quanto aos cuidados necessários mediante tais itens. Os resultados estão expostos na Tabela 4.

Tabela 4 - Aplicação dos indicadores de desempenho Giro de Estoques e Cobertura de Estoques nos produtos classe $A$

\begin{tabular}{|c|c|c|c|c|c|}
\hline Item & Produtos & $\begin{array}{c}\text { Demanda } \\
\text { Anual }\end{array}$ & $\begin{array}{c}\text { Quant. } \\
\text { Mantida em } \\
\text { Estoque }\end{array}$ & $\begin{array}{l}\text { Giro de } \\
\text { Estoque }\end{array}$ & $\begin{array}{c}\text { Cobertura de } \\
\text { Estoques } \\
\text { (dias) }\end{array}$ \\
\hline 1 & $\begin{array}{c}\text { Farinha Trigo Tipo } 1 \\
1 K G\end{array}$ & 28208 & 570 & 49 & 7 \\
\hline 2 & $\begin{array}{c}\text { Queijo Mussarela } \\
1 K G\end{array}$ & 4400 & 60 & 73 & 5 \\
\hline 3 & Salsicha KG & 7365 & 100 & 74 & 5 \\
\hline 4 & $\begin{array}{l}\text { Filé Peito Frango } \\
\text { 1KG }\end{array}$ & 6384 & 240 & 27 & 14 \\
\hline 5 & Carne Simples 1KG & 3150 & 70 & 45 & 8 \\
\hline 6 & Margarina BD 15KG & 329 & 7 & 47 & 8 \\
\hline 7 & $\begin{array}{c}\text { Presunto Cozido } \\
\text { 3,4KG }\end{array}$ & 201 & 40 & 5 & 73 \\
\hline 8 & Queijo Frescal 1KG & 1429 & 50 & 29 & 13 \\
\hline 9 & $\begin{array}{c}\text { Requeijão Catupiry } \\
\text { 1,5KG }\end{array}$ & 2064 & 20 & 103 & 4 \\
\hline 10 & $\begin{array}{l}\text { Azeitona Verde } \\
\text { Fatiada 2KG }\end{array}$ & 403 & 5 & 81 & 5 \\
\hline 11 & $\begin{array}{c}\text { Ovo Branco } 30 \\
\text { Dúzias }\end{array}$ & 135 & 2 & 68 & 5 \\
\hline
\end{tabular}

Fonte: Autoria própria (2019).

Pode-se constatar que os produtos pertencentes a classe A, em sua maioria têm um giro de estoque alto, representando uma boa utilização dos recursos estocados, com exceção do item 7, que é reposto apenas 5 vezes durante o ano, em contrapartida analisando o indicador cobertura de estoque, pode-se concluir 
que o período de tempo que a quantidade mantida em estoque supre a demanda da empresa é curto, sendo assim, o planejamento da produção e estratégico da empresa podem ser prejudicados, devido à necessidade recorrente de reabastecer os estoques de insumos, em sua maioria de forma emergencial. Para equilibrar os resultados desses dois indicadores, precisa-se calcular a real quantidade que deve ser mantida em estoque de cada produto, para que não haja falta ou desperdício desses insumos.

Após a aplicação dos indicadores de desempenho, realizaram-se os cálculos das ferramentas de PCP: estoque de segurança e ponto do pedido, para demonstrar a necessidade do uso delas. Os dados utilizados para desenvolver os cálculos e os respectivos resultados estão expostos na Tabela 5.

Tabela 5 - Aplicação das ferramentas de PCP aos produtos classe A

\begin{tabular}{ccccccc} 
Item & $\begin{array}{c}\text { Média } \\
\text { Consumo } \\
\text { (Mensal) }\end{array}$ & MAD & $\begin{array}{c}\text { Lead Time } \\
\text { (Mensal) }\end{array}$ & $\begin{array}{c}\text { Nivel de } \\
\text { Segurança }\end{array}$ & $\begin{array}{c}\text { Estoque de } \\
\text { Segurança }\end{array}$ & $\begin{array}{c}\text { Ponto } \\
\text { do } \\
\text { Pedido }\end{array}$ \\
1 & 2351 & 34,33 & 0,07 & $90 \%$ & 44 & 209 \\
2 & 367 & 32,33 & 0,23 & $90 \%$ & 41 & 125 \\
3 & 614 & 15,58 & 0,26 & $90 \%$ & 20 & 180 \\
4 & 532 & 20,17 & 0,26 & $90 \%$ & 26 & 164 \\
5 & 263 & 13,67 & 0,03 & $90 \%$ & 18 & 26 \\
6 & 27 & 3,75 & 0,26 & $90 \%$ & 5 & 12 \\
7 & 17 & 3,42 & 0,26 & $90 \%$ & 4 & 8 \\
8 & 119 & 9,08 & 0,23 & $90 \%$ & 12 & 39 \\
9 & 172 & 11,17 & 0,03 & $90 \%$ & 14 & 19 \\
10 & 34 & 3,25 & 0,03 & $90 \%$ & 4 & 5 \\
11 & 11 & 1,92 & 0,07 & $90 \%$ & 3 & 4 \\
\hline
\end{tabular}

Fonte: Autoria própria (2019)

Mediante os valores expostos na Tabela 5, por meio dos cálculos da média de consumo (mensal) e do MAD de cada item, e escolhendo-se o nível de segurança desejado $(k=90 \%)$, foi possível encontrar os valores do estoque de segurança para cada item classificado com Classe A da empresa. Realizou-se, também, o cálculo do ponto do pedido, que indica quando é necessário realizar outra compra de insumos a fim de suprir as demandas da produção diária sem faltar no momento desejado. É possível realizar um comparativo entre as quantidades mantidas em estoque de cada produto atualmente, contidas na Tabela 4, com os valores resultantes das ferramentas de PCP.

Observa-se nos resultados dos cálculos que o item 11 (onze) é mantido abaixo do estoque de segurança, ou seja, a quantidade mantida em estoque é de apenas 2 (duas) unidades do produto, todavia, seriam necessárias no mínimo 3 (três) unidades deste produto. Outra falha encontrada no atual estoque da empresa é que os itens 2 (dois), 3 (três), 6 (seis) e 11 (onze), que representam $36,36 \%$ dos insumos considerados Classe $A$, são mantidos abaixo do ponto do pedido, o que pode resultar na ruptura de estoque e na parada do processo produtivo, o que acarreta para a empresa transtornos que poderiam ser evitados. Comprova-se, portanto, a necessidade de ajustar o sistema de gestão de estoques atualmente utilizado pela empresa. 
Com base no mapeamento do processo e nos resultados dos indicadores de desempenho e das ferramentas de PCP, foi possível identificar as falhas de cada etapa do processo de ressuprimento e os efeitos que mesmas provocam, bem como, realizar a formulação das soluções, as quais estão expressas no Quadro 2.

Quadro 2 - Análise do processo de ressuprimento atual

\begin{tabular}{|c|c|c|c|}
\hline & Falhas & Efeito das falhas & Soluções \\
\hline \multirow{5}{*}{$\begin{array}{l}\text { Requisição de } \\
\text { compras }\end{array}$} & $\begin{array}{l}\text { Não há um } \\
\text { responsável efetivo } \\
\text { pelo setor de } \\
\text { compras }\end{array}$ & \multirow{5}{*}{$\begin{array}{l}\text { •Repetição do processo } \\
\text { de compras diversas } \\
\text { vezes no mesmo dia; } \\
\text { •Custo com combustível } \\
\text { elevado; } \\
\text { •Elevação no preço das } \\
\text { matérias-primas por não } \\
\text { praticar a compra em } \\
\text { grandes lotes; } \\
\text { •Utilização desnecessária } \\
\text { dos recursos financeiros, } \\
\text { de mão-de-obra e espaço } \\
\text { físico dos armazéns; } \\
\text { •Atrasos na produção por } \\
\text { falta de matéria-prima; } \\
\text { •Entrega de pedidos com } \\
\text { atraso. }\end{array}$} & \multirow{5}{*}{$\begin{array}{l}\text {-Definir um responsável } \\
\text { pelo setor de } \\
\text { ressuprimento da } \\
\text { empresa; } \\
\text {-Determinar a política } \\
\text { de compras da empresa } \\
\text { e aplicá-la; } \\
\text {-Utilizar as ferramentas } \\
\text { de Planejamento e } \\
\text { Controle de Produção e } \\
\text { os Indicadores de } \\
\text { Desempenho de Gestão } \\
\text { de Estoques. }\end{array}$} \\
\hline & $\begin{array}{l}\text { Não há uma } \\
\text { política de } \\
\text { compras } \\
\text { formalizada na } \\
\text { empresa } \\
\end{array}$ & & \\
\hline & $\begin{array}{c}\text { Falta de controle } \\
\text { das requisições de } \\
\text { compras }\end{array}$ & & \\
\hline & $\begin{array}{l}\text { Falta de controle } \\
\text { do atendimento das } \\
\text { requisições de } \\
\text { compras }\end{array}$ & & \\
\hline & $\begin{array}{c}\text { Realiza-se a } \\
\text { compra de } \\
\text { materiais a } \\
\text { mais/menos do que } \\
\text { estão contidos no } \\
\text { pedido de compra }\end{array}$ & & \\
\hline \multirow{3}{*}{ Recebimento } & $\begin{array}{l}\text { Falta um } \\
\text { responsável pelo } \\
\text { almoxarifado da } \\
\text { empresa }\end{array}$ & \multirow{3}{*}{$\begin{array}{l}\text { •Baixa acurácia do } \\
\text { estoque; } \\
\text { •Perda de produtos por } \\
\text { avarias; } \\
\text { •Erros no controle do } \\
\text { estoque; } \\
\text {-Desorganização do } \\
\text { processo de } \\
\text { ressuprimento e dos } \\
\text { armazéns. }\end{array}$} & \multirow{3}{*}{$\begin{array}{c}\text {-Definir um responsável } \\
\text { pelo almoxarifado da } \\
\text { empresa; } \\
\text { •Padronizar os } \\
\text { procedimentos de } \\
\text { recebimento; } \\
\text { •Conferir } \\
\text { detalhadamente os itens } \\
\text { recebidos. }\end{array}$} \\
\hline & $\begin{array}{l}\text { Os procedimentos } \\
\text { de recebimento } \\
\text { não são } \\
\text { padronizados }\end{array}$ & & \\
\hline & $\begin{array}{l}\text { Não é realizada a } \\
\text { conferência total } \\
\text { dos itens recebidos }\end{array}$ & & \\
\hline \multirow{3}{*}{ Armazenagem } & $\begin{array}{c}\text { Pouco espaço para } \\
\text { armazenamento } \\
\text { dos materiais }\end{array}$ & \multirow{3}{*}{$\begin{array}{l}\text { •Desorganização do } \\
\text { processo de } \\
\text { ressuprimento e dos } \\
\text { armazéns; } \\
\text { •Baixa otimização do } \\
\text { tempo das atividades; } \\
\text { •Perda de materiais pela } \\
\text { falta do controle de } \\
\text { validade; } \\
\text { •Avarias dos produtos. }\end{array}$} & \multirow{3}{*}{$\begin{array}{c}\text { - Reestruturar o espaço } \\
\text { para armazenamento dos } \\
\text { materiais; } \\
\text { •Criar um método de } \\
\text { identificação das } \\
\text { mercadorias; } \\
\text { •Definir um método de } \\
\text { estocagem; } \\
\text { •Controlar de forma } \\
\text { rígida os produtos classe } \\
\text { A. }\end{array}$} \\
\hline & $\begin{array}{l}\text { Nos armazéns não } \\
\text { há nenhum tipo de } \\
\text { identificação nas } \\
\text { mercadorias como: } \\
\text { nome, código do } \\
\text { produto, validade e } \\
\text { localização do } \\
\text { material }\end{array}$ & & \\
\hline & Não se utiliza um & & \\
\hline
\end{tabular}




\begin{tabular}{|c|c|c|c|}
\hline & $\begin{array}{l}\text { método de } \\
\text { estocagem }\end{array}$ & & \\
\hline & $\begin{array}{l}\text { Não há um } \\
\text { cuidado de } \\
\text { estocagem mais } \\
\text { rígido para } \\
\text { produtos de classe } \\
\text { A da empresa. } \\
\end{array}$ & & \\
\hline \multirow{3}{*}{$\begin{array}{c}\text { Retirada do } \\
\text { estoque }\end{array}$} & $\begin{array}{l}\text { Estoque físico não } \\
\text { é atualizado } \\
\text { constantemente em } \\
\text { relação ao estoque } \\
\text { contábil }\end{array}$ & \multirow{3}{*}{$\begin{array}{c}\text { •Baixa acurácia do } \\
\text { estoque; } \\
\text { •Perda de produtos por } \\
\text { avarias; } \\
\text { •Erros no controle do } \\
\text { estoque; } \\
\text { •Desorganização do } \\
\text { processo de } \\
\text { ressuprimento e dos } \\
\text { armazéns. }\end{array}$} & \multirow{3}{*}{$\begin{array}{l}\text {-Definir um responsável } \\
\text { pelo setor de } \\
\text { ressuprimento da } \\
\text { empresa; } \\
\text {-Padronizar o processo } \\
\text { de retirada de materiais; } \\
\text { •Criar método de } \\
\text { controle para saídas do } \\
\text { estoque. }\end{array}$} \\
\hline & $\begin{array}{c}\text { Falta de } \\
\text { padronização do } \\
\text { processo de } \\
\text { retirada }\end{array}$ & & \\
\hline & $\begin{array}{c}\text { Falta um controle } \\
\text { de retiradas dos } \\
\text { materiais no } \\
\text { estoque }\end{array}$ & & \\
\hline
\end{tabular}

Fonte: Autoria própria (2019)

Após a análise do atual modelo de ressuprimento utilizado pela empresa, pode-se notar que em cada etapa do processo de controle de estoques: Requisição de compras, Recebimento, Armazenagem e Retirada do estoque foram encontradas falhas críticas que inviabilizam a eficiência esperada no setor da administração das matérias-primas e isto afeta diretamente nos custos operacionais da fábrica, além de impedir uma margem de lucro maior para a empresa.

Figura 9 - Mapa de processos sugerido para a empresa

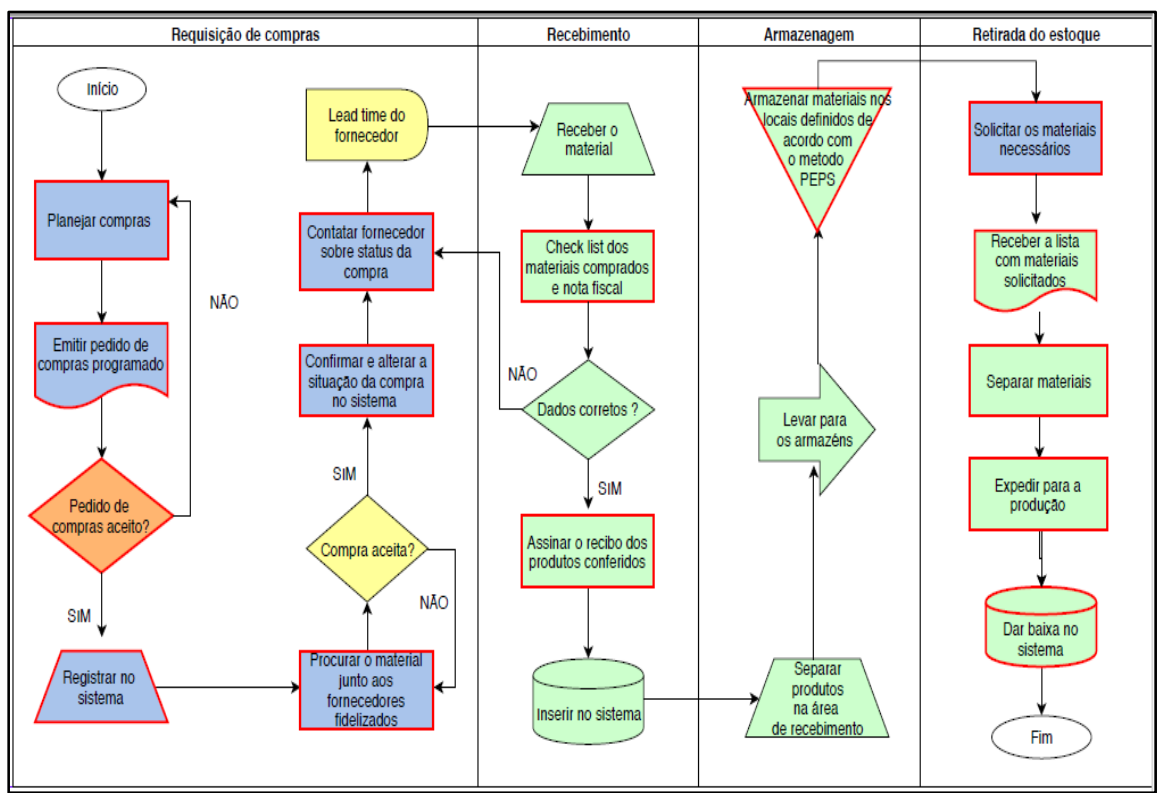




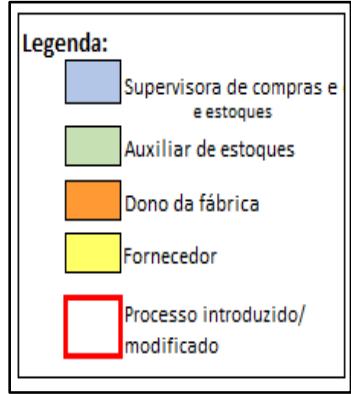

Fonte: Autoria própria (2019)

Foram propostas soluções para amenizar ou sanar falhas encontradas no processo de suprimento de matérias-primas, tendo em vista a importância da correta aquisição, armazenagem e manutenção dos estoques principalmente no que tange aos produtos considerados classe $A$ da empresa. Tais soluções têm como principal objetivo suprir as deficiências existentes na fábrica a fim de aumentar seus rendimentos nas linhas de produção mais rentáveis para a empresa. O novo fluxo de processos sugerido para a empresa pode ser visualizado na Figura 9.

De posse das falhas encontradas no atual modelo de gestão de estoques utilizado pela empresa, fez-se necessário a elaboração de um novo mapa de processos contendo melhorias no atual modelo da fábrica. Para cada novo processo adicionado ou modificado o mesmo foi destacado com bordas vermelhas a fim de uma melhor visualização e compreensão das mudanças feitas. As novas cores do mapa de processos sugerido significam a adição de novas pessoas (colaboradores) no processo.

No modelo atual da empresa não há qualquer programação ou política de compras, por este motivo foi adicionado ao novo mapa o processo de planejamento de compras o qual será executado pelo Supervisor de compras e estoques, para extinguir as compras em emergência existentes hoje. Outro processo de suma importância, a procura do material entre os fornecedores fidelizados, foi introduzido com o propósito de possibilitar a fábrica um maior poder de barganha, menos tempo desperdiçado na procura do material desejado e gastos com combustível reduzidos.

A etapa de recebimento ficará sobre a supervisão do Auxiliar de estoques, o qual ficará sobre sua responsabilidade receber o material entregue a fábrica, fazer o check list dos materiais recebidos e assinar o recibo para dar baixa no sistema tendo como objetivo um controle dos estoques mais eficiente. 0 método PEPS (primeiro a entrar, primeiro a sair) foi proposto a fim de proporcionar uma armazenagem correta dos materiais recebidos tendo em vista as perdas de matérias-primas por data de validade vencida, assim, o item mais antigo do estoque terá preferência na sua saída para utilização.

As mudanças na etapa de retirada do estoque foram necessárias frente às falhas encontradas no modelo atual da empresa, os funcionários da produção tinham livre acesso aos armazéns e não havia nenhum tipo de controle nesta etapa ocasionando uma desorganização no ambiente. No fluxograma proposto pelos autores, o Supervisor de compras e estoques ficará responsável pela solicitação dos materiais desejados junto ao setor de produção da fábrica. A lista com os materiais solicitados será entregue ao Auxiliar de estoques que terá a 
função de separar os mesmos, expedir para a produção e dar baixa no sistema para o controle de saída dos estoques.

Reunidas todas as informações coletadas durante o estudo pôde-se elaborar, por meio da ferramenta de qualidade $5 \mathrm{~W} 1 \mathrm{H}$, um plano de ação apresentado no Quadro 3.

Quadro 3 - Plano de ação 5W1H

\begin{tabular}{|c|c|c|c|c|c|}
\hline $\begin{array}{l}\text { O QUÊ? } \\
\text { (WHAT?) }\end{array}$ & $\begin{array}{c}\text { POR QUE? } \\
\text { (WHY?) }\end{array}$ & $\begin{array}{c}\text { ONDE? } \\
\text { (WHERE?) }\end{array}$ & $\begin{array}{l}\text { QUEM? } \\
\text { (WHO?) }\end{array}$ & $\begin{array}{c}\text { QUANDO } \\
? \\
\text { (WHEN?) }\end{array}$ & $\begin{array}{l}\text { COMO? } \\
\text { (HOW?) }\end{array}$ \\
\hline $\begin{array}{ll}\text { Implantar } & \text { o } \\
\text { modelo } & \\
\text { proposto } & \text { de } \\
\text { gestão } & \text { de } \\
\text { estoques } & \end{array}$ & $\begin{array}{l}\text { Para } \\
\text { padronizar as } \\
\text { atividades do } \\
\text { setor, a fim de } \\
\text { reduzir as } \\
\text { falhas } \\
\text { identificadas e } \\
\text { gerar } \\
\text { melhorias }\end{array}$ & $\begin{array}{l}\text { No setor de } \\
\text { estoques e } \\
\text { compras }\end{array}$ & $\begin{array}{l}\text { Alta } \\
\text { gestão e } \\
\text { responsáv } \\
\text { el pelo } \\
\text { setor de } \\
\text { estoques } \\
\text { e compras }\end{array}$ & $\begin{array}{l}\text { Início em } \\
04 / 02 / 20 \\
20\end{array}$ & $\begin{array}{l}\text { Adequando o } \\
\text { novo modelo } \\
\text { ao setor de } \\
\text { estoques e } \\
\text { compras da } \\
\text { empresa }\end{array}$ \\
\hline $\begin{array}{l}\text { Contratar um } \\
\text { supervisor } \\
\text { para o setor } \\
\text { de estoques e } \\
\text { compras }\end{array}$ & $\begin{array}{l}\text { Para assegurar } \\
\text { a aplicação das } \\
\text { melhorias } \\
\text { propostas }\end{array}$ & $\begin{array}{l}\text { No setor de } \\
\text { RH da } \\
\text { empresa }\end{array}$ & $\begin{array}{l}\text { Responsá } \\
\text { vel pelo } \\
\text { setor de } \\
\text { RH }\end{array}$ & $\begin{array}{l}11 / 02 / 20 \\
20\end{array}$ & $\begin{array}{l}\text { Realizando } \\
\text { um processo } \\
\text { e } \\
\text { recrutamento } \\
\text { e seleção }\end{array}$ \\
\hline $\begin{array}{lr}\text { Definir } & \text { um } \\
\text { auxiliar } & \text { de } \\
\text { estoques } & \end{array}$ & $\begin{array}{l}\text { Para auxiliar } \\
\text { nos processos } \\
\text { relacionados à } \\
\text { gestão de } \\
\text { estoques, a fim } \\
\text { de agilizar as } \\
\text { atividades e } \\
\text { manter a } \\
\text { organização }\end{array}$ & $\begin{array}{l}\text { No setor de } \\
\text { estoques } \\
\text { da empresa }\end{array}$ & $\begin{array}{l}\text { Responsá } \\
\text { vel pelo } \\
\text { setor de } \\
\text { estoques }\end{array}$ & $\begin{array}{l}18 / 02 / 20 \\
20\end{array}$ & $\begin{array}{l}\text { Escolhendo } \\
\text { um } \\
\text { funcionário } \\
\text { da empresa } \\
\text { para exercer } \\
\text { a função }\end{array}$ \\
\hline $\begin{array}{l}\text { Incentivar } \\
\text { programas de } \\
\text { treinamento e } \\
\text { desenvolvime } \\
\text { nto }\end{array}$ & $\begin{array}{l}\text { Para capacitar } \\
\text { os } \\
\text { colaboradores } \\
\text { em suas } \\
\text { funções, para } \\
\text { quer as } \\
\text { desenvolvam } \\
\text { de forma } \\
\text { correta }\end{array}$ & $\begin{array}{l}\text { No setor de } \\
\text { RH da } \\
\text { empresa }\end{array}$ & $\begin{array}{l}\text { Responsá } \\
\text { vel pelo } \\
\text { setor de } \\
\text { RH }\end{array}$ & $\begin{array}{l}\text { Início em } \\
12 / 02 / 20 \\
20\end{array}$ & $\begin{array}{l}\text { Realizando } \\
\text { treinamentos } \\
\text { de } \\
\text { capacitação } \\
\text { conforme as } \\
\text { atividades a } \\
\text { serem } \\
\text { desenvolvidas }\end{array}$ \\
\hline $\begin{array}{l}\text { Reestruturar } \\
\text { os depósitos } \\
\text { de } \\
\text { armazenagem }\end{array}$ & $\begin{array}{l}\text { Para reduzir as } \\
\text { perdas por } \\
\text { mau } \\
\text { acondicioname } \\
\text { nto }\end{array}$ & $\begin{array}{l}\text { Depósitos } \\
\text { de } \\
\text { armazenag } \\
\text { em }\end{array}$ & $\begin{array}{l}\text { Alta } \\
\text { gestão }\end{array}$ & $\begin{array}{l}\text { Início em } \\
18 / 05 / 20 \\
20\end{array}$ & $\begin{array}{l}\text { Ampliando o } \\
\text { espaço de } \\
\text { cada depósito } \\
\text { e comprando } \\
\text { novas } \\
\text { prateleiras }\end{array}$ \\
\hline $\begin{array}{l}\text { Incentivar uso } \\
\text { do sistema } \\
\text { gerencial para }\end{array}$ & $\begin{array}{l}\text { Para controlar } \\
\text { as } \\
\text { movimentaçõe }\end{array}$ & $\begin{array}{l}\text { No setor } \\
\text { administrati } \\
\text { vo }\end{array}$ & $\begin{array}{l}\text { Alta } \\
\text { gestão }\end{array}$ & $\begin{array}{l}\text { Início em } \\
02 / 03 / 20 \\
20\end{array}$ & $\begin{array}{l}\text { Treinando os } \\
\text { colaboradore } \\
\text { s para utilizar }\end{array}$ \\
\hline
\end{tabular}




\begin{tabular}{|c|c|c|c|c|c|}
\hline $\begin{array}{l}\text { controle do } \\
\text { estoque }\end{array}$ & $\begin{array}{l}\text { s do estoque e } \\
\text { tomar decisões } \\
\text { com base nos } \\
\text { dados }\end{array}$ & & & & $\begin{array}{lr}0 & \text { sistema } \\
\text { atual, } & \text { ou } \\
\text { investir } & \text { em } \\
\text { um r novo } & \text { nistema, mais } \\
\text { simples } & \text { e } \\
\text { completo } & \end{array}$ \\
\hline $\begin{array}{l}\text { Utilizar as } \\
\text { ferramentas } \\
\text { de PCP }\end{array}$ & $\begin{array}{l}\text { Para planejar } \\
\text { de forma } \\
\text { assertiva as } \\
\text { necessidades } \\
\text { de compra da } \\
\text { empresa, } \\
\text { promovendo } \\
\text { vantagens } \\
\text { competitivas e } \\
\text { reduzindo } \\
\text { atrasos }\end{array}$ & $\begin{array}{l}\text { No setor de } \\
\text { estoques e } \\
\text { compras }\end{array}$ & $\begin{array}{l}\text { Responsá } \\
\text { vel pelo } \\
\text { setor de } \\
\text { estoques }\end{array}$ & $\begin{array}{l}\text { Início em } \\
04 / 03 / 20 \\
20\end{array}$ & $\begin{array}{l}\text { Atualizando } \\
\text { os cálculos } \\
\text { das } \\
\text { ferramentas } \\
\text { constanteme } \\
\text { nte, com base } \\
\text { nos dados da } \\
\text { empresa }\end{array}$ \\
\hline $\begin{array}{l}\text { Utilizar os } \\
\text { indicadores } \\
\text { de gestão de } \\
\text { estoques }\end{array}$ & $\begin{array}{l}\text { Para verificar a } \\
\text { efetividade do } \\
\text { modelo de } \\
\text { gestão } \\
\text { utilizado nos } \\
\text { estoques, } \\
\text { propondo } \\
\text { melhorias }\end{array}$ & $\begin{array}{l}\text { No setor de } \\
\text { estoques e } \\
\text { compras }\end{array}$ & $\begin{array}{l}\text { Responsá } \\
\text { vel pelo } \\
\text { setor de } \\
\text { estoques }\end{array}$ & $\begin{array}{l}\text { Início em } \\
30 / 03 / 20 \\
20\end{array}$ & $\begin{array}{l}\text { Atualizando } \\
\text { os cálculos } \\
\text { das } \\
\text { ferramentas } \\
\text { constanteme } \\
\text { nte, com base } \\
\text { nos dados da } \\
\text { empresa }\end{array}$ \\
\hline $\begin{array}{l}\text { Formar } \\
\text { parcerias com } \\
\text { fornecedores }\end{array}$ & $\begin{array}{l}\text { Para assegurar } \\
\text { o fornecimento } \\
\text { dos produtos, } \\
\text { redução de } \\
\text { custos e } \\
\text { atendimento } \\
\text { dos pedidos }\end{array}$ & $\begin{array}{l}\text { No setor de } \\
\text { estoques e } \\
\text { compras }\end{array}$ & $\begin{array}{l}\text { Responsá } \\
\text { vel pelo } \\
\text { setor de } \\
\text { estoques }\end{array}$ & $\begin{array}{l}\text { Início em } \\
01 / 04 / 20 \\
20\end{array}$ & $\begin{array}{l}\text { Verificando } \\
\text { os produtos } \\
\text { mais } \\
\text { utilizados, e } \\
\text { quais } \\
\text { fornecedores } \\
\text { oferecem a } \\
\text { melhor oferta } \\
\text { por período e } \\
\text { quantidade }\end{array}$ \\
\hline $\begin{array}{l}\text { Identificar os } \\
\text { itens } \\
\text { armazenados }\end{array}$ & $\begin{array}{ll}\text { Para agilizar a } \\
\text { conferência, } & \\
\text { assegurar } & \\
\text { melhor } & \\
\text { controle } & \text { e } \\
\text { manter } & \text { a } \\
\text { organização } & \end{array}$ & $\begin{array}{l}\text { Depósitos } \\
\text { de } \\
\text { armazenag } \\
\text { em }\end{array}$ & $\begin{array}{l}\text { Responsá } \\
\text { vel pelo } \\
\text { setor de } \\
\text { estoques }\end{array}$ & $\begin{array}{l}\text { Início em } \\
11 / 03 / 20 \\
20\end{array}$ & $\begin{array}{l}\text { Etiquetando } \\
\text { as prateleiras } \\
\text { com os } \\
\text { nomes dos } \\
\text { produtos }\end{array}$ \\
\hline
\end{tabular}

Fonte: Autoria própria (2019)

O plano de ação proposto no Quadro 3 tem como principal objetivo auxiliar a empresa no alcance da eficiência no que diz respeito ao atual modelo de gestão de estoques, aspirando melhorias em todo o processo de ressuprimento de matérias-primas da fábrica. As 5 (cinco) perguntas estratégicas amparam as tomadas de decisão em aspectos relacionados aos estoques da empresa. As datas propostas foram pensadas da melhor forma para não sobrecarregar a empresa no que tange aos investimentos que serão feitos, entretanto todas elas estão 
diretamente relacionadas. As pessoas responsáveis pelas ações a serem tomadas serão contratadas como parte do plano de ação para sua execução.

\section{CONSIDERAÇÕES FINAIS}

O presente estudo teve como principal objetivo, propor adequações, capazes de potencializar o processo de gestão de estoques da fábrica objeto de pesquisa, por meio da utilização de indicadores de desempenho e ferramentas de Planejamento e Controle da Produção (PCP), para atuar em função da redução das falhas decorrentes dos processos associados ao modelo de ressuprimento de materiais atual, as quais interferem na competitividade da empresa.

Para isso, realizou-se o mapeamento do processo atual, a fim de proporcionar a visualização e compreensão de todas as etapas e sequência de atividades atualmente envolvidas no processo de ressuprimento de materiais da empresa, promovendo a identificação dos pontos de origem das falhas, assim como os efeitos que as mesmas resultam, o que possibilitou a formulação de soluções e a construção de um novo mapa do processo de ressuprimento, o qual permitiu realocar, excluir e incluir atividades que potencializaram o processo de gestão de estoques atual, fornecendo um sistema de reposição apropriado ao cenário da empresa. Elaborou-se um plano de ação utilizando a ferramenta $5 \mathrm{~W} 1 \mathrm{H}$, para possibilitar a aplicação das melhorias propostas.

Diante desse contexto, é possível afirmar que a pesquisa alcançou os requisitos impostos inicialmente, a proposta em questão foi atingida mediante a proposição de adequações por meio de indicadores de desempenho e ferramentas de Planejamento e Controle da Produção (PCP), as quais basearamse na análise realizada no mapa de processo atual referente ao modelo de ressuprimento de materiais da fábrica; nas falhas identificadas no processo e em seus respectivos efeitos, com o intuito de sugerir indicadores de desempenho e ferramentas de PCP adequadas para planejamento, avaliação e controle do processo, resultando no mapa de processo sugerido contemplando todas as melhorias propostas.

Como propostas de trabalhos futuros, sugere-se as seguintes proposições:

- Implementar os resultados obtidos nesse estudo, ou seja, a execução do plano de ação $5 \mathrm{~W} 1 \mathrm{H}$ com a implantação das mudanças propostas no mapa de processo sugerido, que incluem medidas que capazes de sanar as falhas encontradas no sistema de ressuprimento da empresa;

- Realizar um estudo do layout dos armazéns, a partir das propostas de investir na reestruturação dos locais de armazenamento e implantação do método de endereçamento, a fim de demonstrar o índice de perdas por avarias dos produtos e as melhorias que podem ser advindas das mudanças propostas, permitindo confirmar se é uma opção viável ou não para a empresa;

- Calcular o lote econômico de compra (LEC), e realizar o planejamento da necessidade de materiais (MRP) e a previsão de demanda de cada produto, a fim de proporcionar um melhor planejamento estratégico e redução nos custos. 


\title{
Proposal for a stock management model: a case study in a small food company in Marabá-PA city
}

\begin{abstract}
Faced of a highly competitive market, enterprises seek a position that enables them to serve their customers with quality, while at the same time reduce the costs involved in their processes. To achieve this balance, the use of well-structured inventory management is essential. In this context, this research presents proposals for adjustments to the inventory management model used by the raw materials management sector of a food factory located in Marabá-PA, based on performance indicators: Inventory Accuracy, Inventory Coverage and Production Planning and Control (PCP) tools: Security Stock and Order Point. The process analysis consisted in mapping the current inventory management model of the company, which enabled the identification of gaps and the proposition of improvements to reduce the flaws in the process. As a result of the work, proposals were made for adjustments to the company's inventory management model, building a new process map with the proposed adaptations, so that the needs of the organization are better met; through the $5 \mathrm{~W} 1 \mathrm{H}$ tool, it was possible to develop a plan of action in order to allow for the future application of the improvements, so that there is a reduction in costs due to losses and delays, contributing to the improvement of the company's competitiveness.
\end{abstract}

KEYWORDS: Inventory Management. Production Planning and Control (PCP). Performance Indicators. 


\section{REFERÊNCIAS}

BALLOU, R. H. Gerenciamento da cadeia de suprimentos. 5. ed. - Porto Alegre: Bookman,2006.

BALLOU, R. H. Logistica Empresarial: transportes, administração de materiais e distribuição física. São Paulo: Atlas, 2015.

BARBROW, S.; HARTLINE, M. Performance Measurement and Metrics Process mapping as organizational assessment in academic libraries. Performance Measurement and Metrics Iss Metrics Iss Performance Measurement and Metrics, 2015. crossref

CHOPRA, S.; MEINDL, P. Gestão da Cadeia de Suprimentos: estratégia; planejamento e operações. 6. ed. São Paulo: Pearson Prentice Hall, 2016.

CHING, H. Y. Gestão de estoque na cadeia logística integrada: supply chain. 4. ed. São Paulo: Atlas, 2010

CORRÊA, H. L.; CORRÊA, C. A. Administração de produção e operações: manufatura e serviços: uma abordagem estratégica. 3. ed. São Paulo: Atlas, 2012.

CORRÊA, Henrique Luiz. Gestão de redes de suprimento: integrando cadeias de suprimentos no mundo globalizado. São Paulo: Atlas, 2010.

CORRÊA, H. L.; GIANESI, I. G. N.; CAON, M. Planejamento, programação e controle da produção: MRP II/ERP conceito, uso e implantação. 5. ed. São Paulo: Atlas, 2011.

DIAS, M. A. P. Administração de materiais: princípios, conceitos e gestão. 6. ed. São Paulo: Atlas, 2012.

FLEURY, P. F.; WANKE, P.; FIGUEIREDO, K. F. Logística empresarial: a perspectiva brasileira. São Paulo: Atlas, 2008.

GAITHER, N.; FRAZIER, G. Administração de Produção e Operações. 8ª edição. São Paulo: Editora Cenpage Learning, 2012.

GANGA, G. M. D. Trabalho de conclusão de curso (TCC) na engenharia de produção: um guia prático de conteúdo e forma. São Paulo: Editora Atlas, 2012. 
GIL, A. C. Como elaborar projetos de pesquisa. 6. ed. São Paulo: Atlas, 2017.

GOMES, F. M.M.; FAUSTINO, G.G.; TONANI, M.; PORCINCULA, S.; SOMERA, S.C.; BEICKER, W.; PAZIN-FILHO, A. Mapeamento do fluxo de trabalho: Engenharia Clínica do HCFMRP-USP. Revista de Medicina USP, 2015.

KRAJEWSKI, L.; RITZMAN, L; MALHOTRA, M. Administração de produção e operações. São Paulo: Prentice Hall, 2009.

LUSTOSA, L.; MESQUITA, M.A.; QUELHAS, O.; OLIVEIRA, R. Planejamento e controle da Produção. Rio de Janeiro: Editora Elsevier, 2008.

MARTINS P.G., ALT P.R.C., Administração de Materiais e Recursos Patrimoniais. 3 ed. São Paulo; Editora Saraiva,2011.

MONTANHEIRO, W. J.; FERNANDES, L. A. Gestão de estoques de materiais em uma confecção. In: SIMPÓSIO DE EXCELÊNCIA EM GESTÃO E TECNOLOGIA, 5., 2008, Resende. Anais: Resende, Associação Educacional Dom Bosco, 2008.

MOURA, Cássia E. Gestão de Estoques. 1ạ. Edição. Rio de Janeiro: Editora Ciência Moderna Ltda., 2004.

PINHO, A.F. Combinação entre as técnicas de fluxograma e mapa de processo no mapeamento de um processo produtivo. In: ENCONTRO NACIONAL DE ENGENHARIA DE PRODUÇÃO, 2007. Anais. Foz do Iguaçu: ABEPRO, 2007.

POZO, H.; Administração de recursos materiais e patrimoniais: uma abordagem logística. 6. ed. São Paulo: Atlas, 2010

PRODANOV, C. C.; FREITAS, E. C. Metodologia do trabalho científico: métodos e técnicas da pesquisa e do trabalho acadêmico. 2. ed. Novo Hamburgo/RS: Universidade FEEVALE, 2013.

SEBRAE. Micro e pequenas empresas geram 27\% do PIB do Brasil. 2015. Disponível em: http://www.sebrae.com.br/sites/PortalSebrae/ufs/mt/noticias/Micro-epequenas-empresas-geram-27\%25-do-PIBdo-Brasil. Acesso em:10/05/2018.

SHETACH, A. Lighting the route to success. Team Performance Management. International Journal, 2011. crossref 
TUBINO, D. F. Manual de planejamento e controle da produção. 3. ed. São Paulo: Atlas, 2017.

VIANA, J. J. Administração de Materiais - Um enfoque prático. São Paulo: Atlas, 2009.

VOLLMANN, T. E. et al. Sistema de planejamento \& controle da produção para gerenciamento da cadeia de suprimentos. 5. ed. Porto Alegre: Bookman, 2006.

WALLER, M. A., et al. Measuring the impact of inaccurate inventory information on a retail outlet. The International Journal of Logistics Management, 2006. crossref

DIAS, Q.D.C.O. et al. Proposta de um modelo de gestão de estoques: um estudo de caso em uma empresa de pequeno porte do ramo alimentício na cidade de Marabá-PA. R. Gest. Industr., Ponta Grossa, v. 16, n. 4, p. 92-120, Out./Dez. 2020. Disponível em: https://periodicos.utfpr.edu.br/revistagi

Correspondência:

Nathália Jucá Monteiro

Tv. Dr. Enéas Pinheiro, 2626 Bairro Marco, Belém, Pará, Brasil.

Direito autoral: Este artigo está licenciado sob os termos da Licença Creative Commons-Atribuição 4.0 Internacional.

\section{(c) (1)}

